\title{
Oreochromis niloticus'un Kas Dokusunda Glutathione S-Transferaz Aktivitesi, Glutatyon ve Protein Miktarı Üzerine Bakır ve Bakırın Kalsiyum Karışımlarının Etkisi
}

\section{Gülbin FíRidìn}

Gazi Üniversitesi, Fen Bilimleri Enstitüsü, Çevre Bilimleri Anabilim Dalı, Ankara, Türkiye

Sorumlu Yazar: gulbinfiridin@gazi.edu.tr

Araştırma Makalesi

Geliş 08 Kasım 2018; Kabul 03 Nisan 2019; Basım 01 Haziran 2019.

\begin{abstract}
Alıntılama: Firidin, G. (2019). Oreochromis niloticus'un kas dokusunda glutathione s-transferaz aktivitesi, glutatyon ve protein miktarı üzerine bakır ve bakırın kalsiyum karışımlarının etkisi. Acta Aquatica Turcica, 15(2), 181-187. https://doi.org/10.22392/actaquatr.480300
\end{abstract}

\section{Özet}

Bu çalışmada Oreochromis niloticus'un kas dokusunda glutatyon S-transferaz aktivitesi ile glutatyon ve protein miktarı üzerine bakır ve bakırın kalsiyum karışımlarının etkisi incelenmiştir. Balıklar 7, 14 ve 28 günlük sürelerle $0,1,0,5$ ve $1,0 \mathrm{ppm}$ $\mathrm{Cu}$ ile kalsiyum karışımlarının $0,1 \mathrm{ppm} \mathrm{Cu}+1,0 \mathrm{ppm} \mathrm{Ca}, 0,5 \mathrm{ppm} \mathrm{Cu}+5,0 \mathrm{ppm} \mathrm{Ca}, 1,0 \mathrm{Cu}$ ppm+10,0 ppm Ca etkisine maruz bırakılmıştır. Kas glutathione S-transferaz aktivitesi bakır ve bakııın kalsiyum karışımlarının etkisinde deney süresi boyunca kontrole göre azalma göstermiştir. Glutatyon miktarı 28. gün $0,1 \mathrm{ppm} \mathrm{Cu}+1,0 \mathrm{ppm} \mathrm{Ca}$ derişimi hariç diğer tüm derişimlerde kontrol grubuna göre artmıştır. Protein miktarı 7.gün $0,5 \mathrm{ppm} \mathrm{Cu}+5,0 \mathrm{ppm} \mathrm{Ca}$ derişimi hariç diğer tüm derişimlerde ve sürelerde kontrole göre azalış göstermiştir. Araştırma sonuçları bakır ve bakırın kalsiyum karışımlarının $O$. niloticus'un kas dokusunda glutathione S-transferaz aktivitesi ile glutatyon ve protein miktarının değişmesine neden olduğunu göstermiştir. Bu değişiklikler bakırın kalsiyum karışımlarının etkisinde bakırın tek başına etkisine göre daha az olmuştur.

Anahtar kelimeler:Bakır, kalsiyum, antioksidan, kas dokusu, Oreochromis niloticus

Effects of Copper and Its Mixtures of Calcium on Glutathione S-Transferase Activity, Levels of Glutathione and Protein in Muscle of Oreochromis niloticus

\begin{abstract}
In this study, the effects of copper and its calcium mixtures on glutathione S-transferase activity, levels of glutathione and protein were examined in the muscle of Oreochromis niloticus. The fish were exposed to $0.1,0.5$ and $1.0 \mathrm{ppm} \mathrm{Cu}$ and 0.1 ppm Cu+1.0 ppm Ca, $0.5 \mathrm{ppm} \mathrm{Cu}+5.0 \mathrm{ppm} \mathrm{Ca}, 1.0 \mathrm{Cu}$ ppm+10.0 ppm Ca for periods of 7, 14 and 28 days. The activity of glutathione S-transferase in muscle showed decrease in the effect of copper and its calcium mixtures compared to the control period. Glutathione level increased in all concentrations with respect to the control group except for concentration of $0.1 \mathrm{ppm}$ $\mathrm{Cu}+1.0 \mathrm{ppm} \mathrm{Ca}$ for 28 days. The results of the study revealed that copper and its mixtures of calcium caused a change in glutathione S-transferase activity and protein level in the muscle tissue of O. niloticus. These changes were less in the effect of copper calcium mixtures than the effect of copper alone.
\end{abstract}

Keywords: Copper, calcium, antioxidant, muscle tissue, Oreochromis niloticus

\section{GíRiș}

Doğal dengeyi bozan kirleticiler arasında olan ağır metaller biyolojik olarak parçalanmazlar ve doğada birikerek organizmalara toksik etki yaparlar. Omurgalılar için önemli bir iz element olan bakır çok sayıda biyokimyasal reaksiyonlarda görev almaktadır (Lall, 2002). Bakırın yüksek derişimleri, doku ve organlarda birikime, besin zinciri aracılığı ile artan derişimlerde üst trofik düzeylere taşınmaya, metabolik ve fizyolojik olaylarda değişikliklere neden olmaktadır (Abbas ve Ali, 2007). Kalsiyum organizmalarda kasların kasılmasında, salgı hücrelerinin sekresyonunda, ekstraselüler protein ve enzimlerde kofaktör olarak görev almaktadır (Hunn, 1985).

Bir elementin toksisitesi kimyasal yapısına, konsantrasyonuna, ortamda bulunan diğer metallerle etkileşimine, fizikokimyasal faktörlere, dokuların işlevsel ve fizyolojik durumuna bağlı olarak değişebilmektedir (Karthikeyan vd., 2007). 
Uzun süreli bakır etkisinde doku ve organlarda birikim, anatomik, morfolojik, metabolik, fizyolojik ve biyokimyasal olaylarda değişiklikler meydana gelmektedir (Handy, 2003).

Ağır metaller sucul organizmalarda, antioksidan savunma sistemlerini etkilemekte ve reaktif oksijen türlerinin (ROS) üretimine yol açarak oksidatif hasara neden olmaktadır (Liu vd., 2006; Monteiro vd., 2006). Antioksidan sistemler organizmada ROS'un detoksifikasyonunda rol almaktadırlar. Glutatyon S-transferaz (GST), hücresel bileşenleri çeşitli toksik etkilere ve oksidatif strese karşı korumada görevli sitozolik savunma sistemidir ve elektrofilik karbon, nitrojen veya sülfür atomu vererek glutatyonun moleküllere nükleofilik bağlanmasını katalizlemektedir (Hayes vd., 2005). Glutatyon (GSH), düşük moleküler ağırlıklı bir antioksidandır ve organizmalarda oksidatif stres biyomarkırı olarak değerlendirilmektedir. Proteinler, hücre homeostasisini korumak için önemli fizyolojik olaylarda yer almaktadır. Bundan dolayı hücre proteinlerinin durumu, hücrenin fizyolojik fazlarını belirlemek için bir teşhis aracı olarak kullanılabilmektedir (Karthikeyan ve Mani, 2014).

Kas dokusu metabolik aktivite bakımından solungaç, karaciğer ve böbrek gibi organlarla karşılaştırıldığında daha az aktiftir. Ancak balık kas dokusu besin zincirinde önemli bir besin kaynağı olması nedeniyle metal toksisite çalışmalarında belirteç olarak çalışılmaktadır (De La Torre vd., 2007).

Ağır metal etkisinde, balıkların biyokimyasal parametrelerindeki değişimler balığın fizyolojik durumu ile ortamdaki kirlilik düzeyini yansıtabilmektedir. Balıklar, sucul ekosistemlerdeki besin zincirinin önemli bir halkasını oluşturmakta ve önemli bir protein kaynağı olarak tüketilmektedir. Kemikli bir balık türü olan $O$. niloticus dünya genelinde yaygın bir şekilde bulunmakta olup çeşitli çevre faktörlerine karşı dirençli olması ve kolay yetiştirilebilmesi nedeniyle su ekosistemlerinin incelenmesi ve toksikolojik çalışmalar için iyi bir model oluşturmaktadır.

\section{MATERYAL ve YÖNTEM}

Deneyde kullanılan $O$. niloticus'lar Çukurova Üniversitesi Su Ürünleri Fakültesi balık yetiştirme havuzlarından alınarak laboratuvara getirilmiş ve dinlendirilmiş çeşme suyu bulunan akvaryumlar içerisinde iki ay süre ile bekletilerek ortam koşullarına adaptasyonları sağlanmıştır. Bu süre içerisinde balıklar ortalama $17,25 \pm 0,38 \mathrm{~cm}$ boy ve $32,85 \pm 0,37 \mathrm{~g}$ ağırlığa ulaşmıştır. Balıklar hazır balık yemi ile beslenmişlerdir.

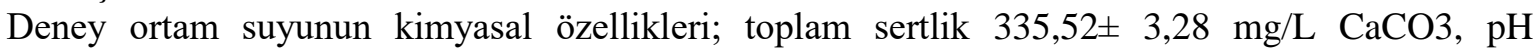
$8.34 \pm 0.005$, çözünmüş oksijen $7,84 \pm 0,24 \mathrm{mg} / \mathrm{L}$, akvaryum 1 sıss $22,06 \pm 0,62^{\circ} \mathrm{C}$ olarak ölçülmüştür.

Deneyler iki seri olarak yürütülmüştür. Balıklar birinci seride bakırın $\left(\mathrm{CuSO}_{4} .5 \mathrm{H}_{2} \mathrm{O}\right) 0,1,0,5$ ve 1,0 ppm derişimlerinin; ikinci seride ise bakırın kalsiyum karışımlarının $0,1 \mathrm{ppm} \mathrm{Cu}+1,0 \mathrm{ppm} \mathrm{Ca}$ $\left(\mathrm{CaSO}_{4} \cdot 2 \mathrm{H}_{2} \mathrm{O}\right), 0,5 \mathrm{ppm} \mathrm{Cu}+5,0 \mathrm{ppm} \mathrm{Ca}, 1,0 \mathrm{Cu}$ ppm+10,0 ppm Ca derişimlerinin etkisine 7, 14 ve 28 gün sürelerle bırakılmışlardır. Kontrol olarak dinlendirilmiş çeşme suyu kullanılmıştır.

Deneyler üç tekrarlı yapılmış ve deneme süresince 126 adet balık kullanılmıştır. Deneme süresi sonunda balıkların kas dokuları disekte edilmiş ve izotonik \%0,59'luk soğuk $\mathrm{NaCl}$ çözeltisi ile yıkanmıştır. Dokular, analizleri yapılana kadar $-80^{\circ} \mathrm{C}$ 'de saklanmıştır. GST aktivitesi ile GSH ve protein miktarlarının belirlenmesi için dokular üzerine ağırlıklarının 1/10'u oranında homojenizasyon tamponu eklenerek (250 mM sukroz, $20 \mathrm{mM}$ Trizma-Baz, 1mM EDTA, pH: 7,8) $9500 \mathrm{rpm}$ 'de 1,5 dk süreyle buz üstünde homojenize edilmiştir. Homojenatlar $10.000 \mathrm{~g}$ 'de $+4^{\circ} \mathrm{C}$ ' de $20 \mathrm{dk}$ santrifüj edilmiş ve elde edilen süpernatantlarda GST (Habig vd., 1974), GSH (Anderson, 1985) ve protein miktarı (Lowry vd., 1951) spektrofotometrik olarak ölçülmüştür.

Analizlerden elde edilen verilerin istatistik analizi (Aritmetik Ortalama \pm Standart Hata), IBM SPSS Statistics 20.0 paket programında yapılmıştır. Deney grupları arasındaki istatistiksel ayrımlar Tek Yönlü Varyans Analizi takiben çoklu karşılaştırma testlerinden Student - Newman Keul's (SNK) Testi kullanılarak belirlenmiştir.

\section{BULGULAR}

Bakır ve bakırın kalsiyum karışımlarının etkisine 7, 14 ve 28 gün süreyle bırakılan $O$. niloticus'un kas dokusundaki GST aktivitesi ile GSH ve protein miktarlarındaki değişiklikler Tablo 1, 2 ve Şekil 1 de verilmiştir.

Kas GST aktivitesi bakır derişimlerinin etkisinde denenen tüm sürelerde kontrole göre istatistiksel olarak önemli bir oranda azalmıştır $(\mathrm{P}<0,005) .1 .0 \mathrm{ppm} \mathrm{Cu}$ ve $1.0 \mathrm{ppm} \mathrm{Cu}+10.0 \mathrm{ppm} \mathrm{Ca}$ derişiminde 
$7,14,28$. günlerde kontrole göre sırasıyla; $\% 57$ ve $\% 69 ; \% 88,5$ ve $\% 36 ; \% 88,8$ ve $\% 50$ oranlarında azalış olmuştur. 14. gün $1,0 \mathrm{ppm} \mathrm{Cu}+10.0 \mathrm{ppm} \mathrm{Ca}$ karışımı hariç tüm derişimlerde bu azalış istatistiksel olarak önemli olmuştur. $1.0 \mathrm{ppm} \mathrm{Cu}$ etkisinde 14 ve 28 . günde 7 . güne göre $\% 75$ ve $\% 79$ artış olmuştur. GST aktivitesinde $0,5 \mathrm{ppm} \mathrm{Cu}+5,0 \mathrm{ppm} \mathrm{Ca}$ etkisinde süreler arasında 28. günde 14 . güne göre $\% 154$ oranında artış olurken $(\mathrm{P}<0,005)$ diğer derişimlerde süreler arasında istatistiksel olarak önemli değişiklik olmamıştır ( $\mathrm{P}>0,005)$ (Tablo 1).

Kas GSH miktarı $\mathrm{Cu}$ ve $\mathrm{Cu}+\mathrm{Ca}$ karışımlarının etkisinde kontrole göre artış göstermiştir. 0,5 ppm $\mathrm{Cu}$ hariç hiçbir derişimde süreler arasında önemli değişiklik olmamıştır $(\mathrm{P}>0,005)$. 0,5 ppm Cu derişiminde GSH miktarı 14. ve 28. günde 7. güne göre $\% 24$ ve $\% 161,9$ oranında artmıştır $(P<0.05)$. GSH miktarında 28. günde 1,0 ppm Cu ve 1,0 ppm Cu+10,0 ppm Ca derişiminde kontrole göre sirayla 5 katlık ve 2 katlık artış kaydedilmiştir. GSH miktarı $0,1 \mathrm{ppm} \mathrm{Cu}$ derişiminde 7,14 ve 28. günlerde kontrole göre sirasiyla \%41, \%34 ve \%66; $0,5 \mathrm{ppm} \mathrm{Cu}$ ve $0,5 \mathrm{ppm} \mathrm{Cu}+5 \mathrm{ppm} \mathrm{Ca}$ derişimlerinde kontrole göre sirasıyla 7 . günde $\% 47,5$ ve $\% 10 ; 14$. günde $\% 61$ ve $\% 8,6 ; 28$. günde $\% 270$ ve $\% 45$ oranında artmıştır $(\mathrm{P}<0.05)$. Kas GSH miktarındaki artış $0,1 \mathrm{ppm} \mathrm{Cu}+1,0 \mathrm{ppm} \mathrm{Ca}$ derişimi hariç diğer tüm derişimlerde sürenin ilerlemesiyle artmıştır (Tablo 1).

Kas protein miktarı $\mathrm{Cu}$ ve $\mathrm{Cu}+\mathrm{Ca}$ derişimleri etkisinde denenen her üç sürede kontrol grubuna göre azalmıştır. 28. günde kontrole göre sırasıyla $0,1 \mathrm{ppm} \mathrm{Cu}$ ve $0,1 \mathrm{ppm} \mathrm{Cu}+1,0 \mathrm{ppm} \mathrm{Ca}$ derişimlerinde $\% 29,5$ ve \%31,9; $0,5 \mathrm{ppm} \mathrm{Cu}$ ve $0,5 \mathrm{Cu}+5,0 \mathrm{ppm} \mathrm{Ca}$ derişimlerinde \%68,5 ve \%25; $1,0 \mathrm{ppm} \mathrm{Cu}$ ve 1,0 ppm $\mathrm{Cu}+10,0 \mathrm{ppm} \mathrm{Ca}$ derişimlerinde $\% 68$ ve \%25 oranında azalmıştır $(\mathrm{P}<0,05) .0,5 \mathrm{ppm} \mathrm{Cu}+5,0 \mathrm{ppm}$ $\mathrm{Ca}$ karışımı hariç diğer derişimlerde süreler arasında istatistiksel olarak önemli değişiklik olmamıştır $(\mathrm{P}>0,005)$.

\section{TARTIŞMA ve SONUÇ}

Metaller balıklarda fizyolojik ve biyokimyasal mekanizmaların bütünlüğünü bozabilmekte ve böylece oksidatif stresi indükleyebilmektedir (Livingstone, 2003). Bakır ve bakırın kalsiyum karışımlarının etkisine 7, 14 ve 28 günlük süreyle bırakılan $O$. niloticus kas dokusunda kontrol grubuna göre GST aktivitesi ile GSH ve protein miktarlarında değişiklikler kaydedilmiştir. Bakır kalsiyum karışımları etkisinde bakırın tek başına etkisine göre daha az değişiklik belirlenmiştir.

O. niloticus ile yapılan bir çalışmada dokularda kadmiyum birikimi kalsiyum varlığında azalmıştır. Araştırıcılar bu azalmanın kalsiyumun su sertliğini yükseltmesinden ve sert sularda metallerin daha az aktif olmasından kaynaklanabileceğini bildirmişlerdir (Çoğun ve Reyhan, 2016). Fundulus heteroclitus ile yapılan bir çalışmada tuzlu suyun bakır toksisitesini azalttı̆̆ 1 ve bu durumun aynı bağlanma bölgeleri için bakır ve tuzlu sudaki katyonlar arasındaki rekabetin artmasından ve aynı zamanda tuzlu suyla etkileşen modifiye edilmiş bir solungaç fenotipinden kaynaklanabileceğini bildirmişlerdir. (Scott vd., 2008; Ransberry vd., 2015). Matsuo vd. (2004), kalsiyumun bakır toksisitesi üzerine antagonistik etkisinin olduğunu belirtmişlerdir. Pelteobagrus fulvidraco'un solungaç, böbrek ve kas dokularında bakır birikimini kalsiyumun azalttığı ve bakır toksisitesine karşı kalsiyumun koruyucu etkisinin olduğu ileri sürülmüştür (Chen vd., 2012). Kalsiyumun solungaçlarda bakır bağlanma bölgeleri için bakır ile rekabet ettiği ve solungaçlardan kana bakırın tutulmasını ve transferini önlediği bildirilmektedir (Santore vd., 2001). Abdel-Tawwab vd. (2007), O. niloticus ile yaptıkları bir çalı̧̧mada kalsiyumun bakır toksisitesini azaltma kapasitesine sahip olduğunu göstermişlerdir.

Balıklar, kimyasalların ve diğer ksenobiyotiklerin parçalanmasından oluşan reaktif oksijen türlerinin (ROS) etkisine karşı savunma sistemine sahiplerdir (Ayanda vd., 2018) ve oksidatif stres altında antioksidan enzimleri kolayca indüklenebilir hale gelebilmektedir (Di Giulio vd., 1989).

GST ve GSH gibi antioksidan sistemler oksidatif strese neden olan ROS oluşumunu önlemek için önemlidirler (Tripathi vd., 2006). GST, GSH'ın çeşitli bileşiklere bağlanmasını kataliz etmekte ve reaktif bileşiklerin transportunu ve eliminasyonunu sağlamaktadır (Livingstone, 2003). Çalışılan tüm derişimlerde ve sürelerde bakır ve bakırın kalsiyum karışımlarının etkisinde kas GST düzeyi kontrole göre azalmıştır. Bu azalma tek başına bakır etkisinde daha fazla olmuştur. Enzim aktivitesindeki azalışlar enzim yapısındaki -SH gruplarına metalin bağlanmasından kaynaklanabilmektedir. Önceki çalışmalar bakır uygulamasının türe, konsantrasyona ve uygulama yöntemine bağlı olarak antioksidan enzim aktivitelerini ya aktive ettiğini ya da inhibe ettiğini göstermektedir (Sanchez vd., 2005). Pereira vd. (2013), endüstri atık sularının bırakıldığı bölgelerden alınan çeşitli balık türleriyle (Luciobarbus 
bocagei, Squalius carolitertii ve Pseudochondrostoma sp.) yaptıkları bir çalışmada solungaç GST aktivitesinin kirlilik yoğunluğunun artmasına bağlı olarak arttığını göstermişlerdir. Bakır uygulamasının Rhamdia quelen dokularında biyotransformasyonu ve antioksidan kapasiteyi etkilediği gösterilmiştir (Mela vd., 2013). Prochilodus lineatus ile yapılan bir çalışmada ise bakır etkisinde karaciğer dokusu GST aktivitesi ve GSH miktarı değişmemiştir (Simonato vd., 2016).

Oksiradikal temizleyicisi olan GSH, organizmaların detoksifikasyon yeteneğinde çok önemli bir indikatör olabilmektedir (Sun vd., 2006). Balık hücreleri metal gibi bazı kirleticilere maruz kaldığında genellikle onları doğrudan GSH ile bağlayarak uzaklaştırmaya çalışmaktadır. GSH kadmiyum gibi metalleri de içeren ksenobiyotiklere karşı antioksidan sistemin ilk basamağını oluşturmaktadır (Santovito vd., 2012). Sülfidril grubunun metalle doğrudan bağlanması GSH düzeyinin azalmasının nedeni olduğu ileri sürülmektedir (Elia vd., 2003). Kas GSH miktarı denenen tüm sürelerde ve metal karışımlarının etkisinde kontrole göre artış göstermiştir. Bu durumun metal etkisinde oluşan oksidatif strese karşı balığı korumak için savunma sisteminin artmasından kaynaklanabildiği düşünülmektedir. Kadmiyum etkisinin Carassius auratus'un karaciğer dokusunda GSH miktarını artırdığı bildirilmiştir (Qu vd., 2014).

Proteinler enerji üretimi ve metal detoksifikasyonunda görev almakta ve toksisite sirasinda metabolik olaylardaki değişiklikleri yansıtmaktadır. Balıklar, ağır metal ve stres etkisi altında enerji gereksinimlerini karbonhidrat ve proteinlerden sağlamaktadırlar (Vijayan vd., 1997). Bu araştırmada kas protein miktarı denenen tüm derişimlerde ve sürelerde kontrole göre azalma göstermiştir. Torre vd. (2000), dokularda protein düzeyinin azalmasını balıkların metal etkisinde oluşan stresi yenmek için gerekli olan enerjiyi, protein katabolizmasının stimülasyonu ile sağlamasından kaynaklanabileceğini bildirmişlerdir. Cyprinus carpio ile yapılan bir çalışmada protein miktarının azalmasının, kas doku proteinlerinin katabolik ürünlerinin karaciğerdeki protein sentezinde kullanılmasından ve bu amaçla serbest amino asitlerin dolaşım sistemine geçmesinden olabileceği ileri sürülmüş̧ür (Cicik, 1995). Çeşitli balık türleri ile yapılan çalışmalarda metallerin kas protein derişimini azalttı̆̆ belirlenmiştir (Almeida vd., 2001; Mohamed ve Gad, 2008). Clarias lazera ile yapılan bir araştırmada bakırın ortam derişimindeki artışına bağlı olarak kas total protein derişimini azalttığını ve bu durumun metal etkisinde artan enerji ihtiyacının kas proteinlerinin mobilizasyonuyla sağlanmasından ya da metalin alınım, taşınım ve depolanmasında görev alan proteinlerin sentezi için gerekli amino asitlerin, kas proteinlerinin yıkımı ile karşılanmasından kaynaklanabileceği bildirilmiştir (Arslan, 2006). Çiftçi ve Cicik (2011), çeşitli balık türleriyle yaptıkları bir çalışmada krom etkisinde dokulardaki protein miktarına bakmışlardır. İncelenen türlerde total protein düzeyi ortam derişimi ve etkide kalma süresindeki artışa bağlı olarak azalmıştır. Kadmiyum, bakır ve bu metallerin karışımlarının etkisine bırakılan $O$. niloticus'un kas dokularında protein düzeyi kontrole göre önemli bir şekilde düşüş göstermiştir (El-Serafy vd., 2013). Bakır etkisinde $C$. carpio'da karaciğer protein düzeyi artarken kas dokusu protein düzeyi azalmıştır (Cicik vd., 2004). Cirrhinus mrigala balı̆ğ ile yapılan bir çalışmada balık kas dokusunda protein miktarı nikel ve krom etkisinde azalmıştır (Karthikeyana ve Mani, 2014).

Sonuç olarak çalış1lan parametrelerde tüm deney süresince kalsiyumun bakır etkisini azalttığ1 belirlenmiştir. Bu durumun metal karışımlarının GST aktivitesi ile GSH ve protein miktarlarına etkisinin, bu iki metalin proteinlerdeki bağlanma bölgelerindeki ya da solungaçlardaki alınım bölgelerindeki rekabetinden kaynaklanabileceği düşünülmektedir. Akuatik ortamda metal toksisitesinin çalışılması sucul ekosistemin dengesi, geleceği ve su ürünlerinin sürdürülebilirliği bakımından oldukça önemlidir. Doğal ve laboratuvar ortamında farklı indikatörlerin araştırılmasıyla, konunun daha derin incelenmesinin sağlanabileceği düşünülmektedir. 
Tablo 1. Bakır ve bakır kalsiyum karışımlarının etkisine 7, 14 ve 28 gün sürelerle bırakılan O. niloticus'un kas dokusunda GST aktivitesi (U/mg protein).

\begin{tabular}{|c|c|c|c|}
\hline \multirow{2}{*}{$\begin{array}{l}\text { Metal konsantrasyonları } \\
\text { (ppm) }\end{array}$} & \multicolumn{3}{|c|}{ Süre } \\
\hline & 7. Gün & 14. Gün & 28. Gün \\
\hline Kontrol & $4,315+0,430$ ax & $3,954+0,927$ ax & $3,424+0,519$ ax \\
\hline $0,1 \mathrm{ppm} \mathrm{Cu}$ & $1,734+0,340 \mathrm{bx}$ & $2,054+0,375 \mathrm{abx}$ & $1,454+0,378 \mathrm{bx}$ \\
\hline $0,1 \mathrm{ppm} \mathrm{Cu}+1,0 \mathrm{ppm} \mathrm{Ca}$ & $2,159+0,545 \mathrm{bx}$ & $1,032+3,50 \quad b x$ & $1,673+0,418$ bx \\
\hline Kontrol & $4,315+0,430$ ax & $3,954+0,927$ ax & $3,424+0,519$ ax \\
\hline $0,5 \mathrm{ppm} \mathrm{Cu}$ & $1,056+0,438 \mathrm{bx}$ & $0,91+0,332 \quad b x$ & $0,835+0,537 \mathrm{bx}$ \\
\hline $0,5 \mathrm{ppm} \mathrm{Cu}+5,0 \mathrm{ppm} \mathrm{Ca}$ & $1,039+0,290 \mathrm{bx}$ & $1,022+0,283 \quad b x$ & $2,601+0,236$ ay \\
\hline Kontrol & $4,315+0,430$ ax & $3,954+0,927$ ax & $3,424+0,519$ ax \\
\hline $1,0 \mathrm{ppm} \mathrm{Cu}$ & $1,844+0,483 \mathrm{bx}$ & $0,455+0,041$ by & $0,385+0,206$ by \\
\hline $1,0 \mathrm{Cu} \mathrm{ppm}+10,0 \mathrm{ppm} \mathrm{Ca}$ & $1,325+0,097 \mathrm{bx}$ & $2,521+0,396$ ax & $1,710+0.306 \mathrm{cx}$ \\
\hline
\end{tabular}

a, b, c harfleri konsantrasyonlar; $\mathrm{x}$, y harfleri ise süreler arası ayrımı belirlemek amacı ile kullanılmıştır.

Farklı harflerle gösterilen veriler arasında $\mathrm{P}<0,05$ düzeyinde istatistik ayrım vardır. (SNK; $\mathrm{X}+\mathrm{sx}$ )

Tablo 2. Bakır ve bakır kalsiyum karışımlarının etkisine 7, 14 ve 28 gün sürelerle bırakılan O. niloticus'un kas dokusunda GSH miktarı ( $\mu \mathrm{M} / \mathrm{mg}$ protein).

\begin{tabular}{|c|c|c|c|}
\hline \multirow{2}{*}{$\begin{array}{l}\text { Metal konsantrasyonları } \\
\text { (ppm) }\end{array}$} & \multicolumn{3}{|c|}{ Süre } \\
\hline & 7. Gün & 14. Gün & 28. Gün \\
\hline Kontrol & $0,491+0,047$ ax & $0,557+0,050$ ax & $0,512+0,037$ ax \\
\hline $0,1 \mathrm{ppm} \mathrm{Cu}$ & $0,694+0,037$ ax & $0,748+0,042 \mathrm{bx}$ & $0,851+0,067 \mathrm{bx}$ \\
\hline $0,1 \mathrm{ppm} \mathrm{Cu}+1,0 \mathrm{ppm} \mathrm{Ca}$ & $0,593+0,060$ ax & $0,692+0,026$ abx & $0,459+0,068$ ax \\
\hline Kontrol & $0,491+0,047$ ax & $0,557+0,050$ ax & $0,512+0,037$ ax \\
\hline $0,5 \mathrm{ppm} \mathrm{Cu}$ & $0,724+0,055 \mathrm{bx}$ & $0,898+0,043$ by & $1,896+0,337$ by \\
\hline 0,5 ppm Cu+5,0 ppm Ca & $0,543+0,040$ ax & $0,605+0,272$ ax & $0,744+0,090$ ax \\
\hline Kontrol & $0,491+0,047$ ax & $0,557+0,050$ ax & $0,512+0,037$ ax \\
\hline $0,5 \mathrm{ppm} \mathrm{Cu}$ & $0,724+0,055 \mathrm{bx}$ & $0,898+0,043$ by & $1,896+0,337$ by \\
\hline $0,5 \mathrm{ppm} \mathrm{Cu}+5,0 \mathrm{ppm} \mathrm{Ca}$ & $0,543+0,040$ ax & $0,605+0,272$ ax & $0,744+0,090$ ax \\
\hline
\end{tabular}

a, b, c harfleri konsantrasyonlar; $\mathrm{x}$, y harfleri ise süreler arası ayrımı belirlemek amacı ile kullanılmıştır.

Farklı harflerle gösterilen veriler arasında $\mathrm{P}<0,05$ düzeyinde istatistik ayrım vardır. ( $\mathrm{SNK}$; $\mathrm{X}+\mathrm{sx}$ )

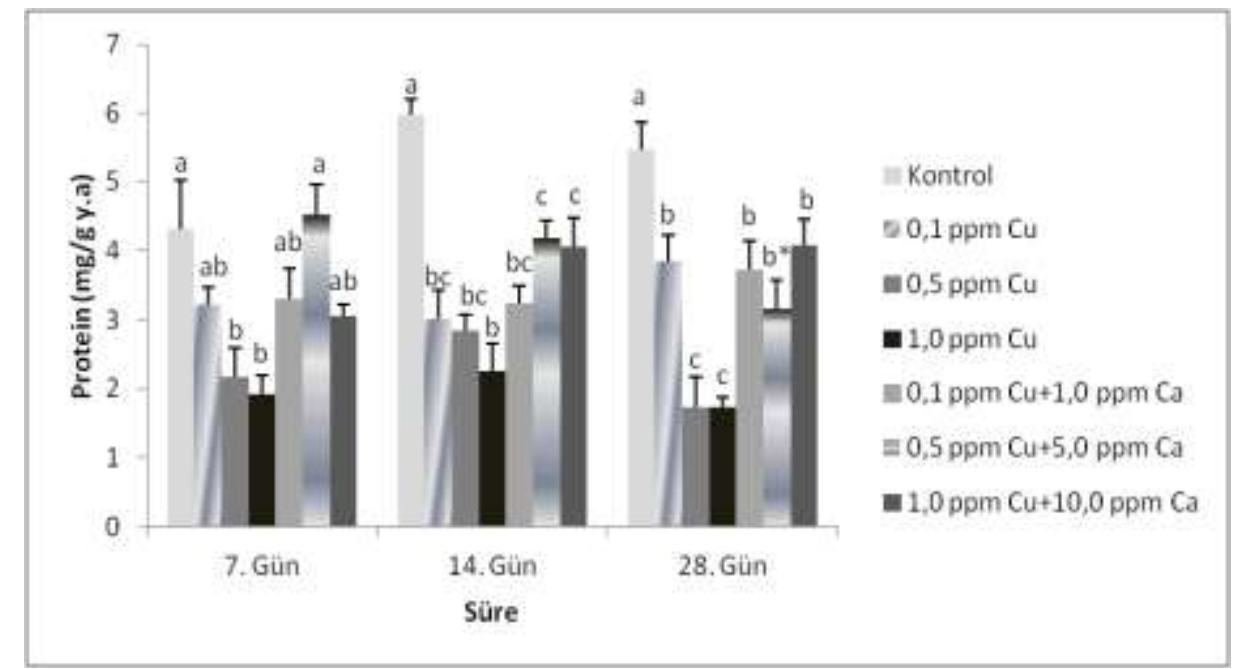

Şekil 1. Bakır ve bakır kalsiyum karışımlarının etkisine 7, 14 ve 28 gün sürelerle bırakılan O. niloticus'un kas dokusunda protein miktarı (mg/g y.a) 


\section{KAYNAKLAR}

Abbas, H., H., \& Ali, F. K. (2007). Study the effect of hexavalent chromium on some biochemical, citotoxicological and histopathological aspects of the Orechromis spp. Fish. Pakistan Journal of Biological Sciences, 10, 3973-3982. doi: 10.3923/pjbs.2007.3973.3982

Abdel-Tawwab, M., Abdelghany, A. E., \& Ahmad, M. H. (2007). Effect of feed supplementation on water properties, phytoplankton community structure and the growth of Nile tilapia, Oreochromis niloticus (L.), common carp, Cyprinus carpio L., and silver carp, Hypophthalmichthys molitrix V. Polycultured in fertilized earthen ponds. Journal of Applied Aquaculture, 19, 1-24. doi: 10.1300/J028v19n01_01

Almeida, J. E., Novelli, M., Silva, D. P., \& Junior, R. (2001). Environmental cadmium exposure and metabolic responses of the Nile tilapia Oreochromis niloticus. Environmental Pollution, 114, 169-175. doi: 10.1016/S0269-7491(00)00221-9

Anderson, M. E. (1985). Determination of glutathione and glutathione disulfide in biological samples. Methods in Enzymology, 113, 548-555.

Arslan, M., (2006). Farklı ortam derişimlerindeki bakırın, Clarias lazera (Valenciennes, 1840)’DA nicel protein, glikojen ve bazı kan parametreleri üzerine etkileri, Yüksek Lisans Tezi, Mersin Üniversitesi, Fen Bilimleri Enst. Mersin.

Ayanda, I. O., Olasehinde, G. I., \& Ajayi, A. A. (2018). Toxicity of sublethal concentrations of glyphosate and paraquat herbicide in the African catfish (Clarias gariepinus). International Journal of Agriculture and Biology., 20 (6), 1359-1364. doi: 10.17957/IJAB/15.0642

Chen, Q. L., Luo, Z., Zheng, J. L., Li, X. D., Liu, C. X., Zhao, Y. H., \& Gong, Y. (2012). Protective effects of calcium on copper toxicity in Pelteobagrus fulvidraco: copper accumulation enzymatic activities, histology. Ecotoxicology and Environmental Safety, 76, 126-134. doi: 10.1016/j.ecoenv.2011.10.007

Cicik, B., Ay, Ö., \& Karayakar, F. (2004). Cyprinus carpio (L.)' da bakırın kas ve karaciğer dokularındaki birikiminin total protein derişimi üzerine etkileri Süleyman Demirel Üniversitesi Eğirdir Su Ürünleri Fakültesi Dergisi, 2(12), 26-31.

Cicik, B. (1995). Cyprinus carpio'da Bakır, çinko ve bakır + çinko karışımında solungaç, karaciğer ve kas dokularındaki metal birikiminin nicel protein, glikojen ve kandaki bazı biyokimyasal parametreler üzerine etkileri. Doktora Tezi, Çukurova Üniversitesi Fen Bilimleri Enst. Biyoloji ABD, Adana, $107 \mathrm{~s}$.

Çiftçi, N., \& Cicik, B. (2011). Krom (VI)'nın Oreochromis niloticus, Cyprinus carpio, Clarias gariepinus ile Callinectes sapidus'un Dokularında Birikimi, Protein ve Glikojen Düzeylerine Etkileri. Süleyman Demirel Üniversitesi Ĕ̈irdir Su Ürünleri Fakültesi Dergisi, 7(2), 37-55.

Çoğun, H., Y., \& Reyhan, İ. Ç. (2016). Tilapia (Oreochromis niloticus Linnaeus, 1758) balığı dokularında kalsiyum ve zeolitin kadmiyum birikimine etkisi. Ege Journal of Fisheries and Aquatic Sciences, 33(1), 41-46. doi: 10.12714/egejfas.2016.33.1.07

Torre, F., Salibian, A., \& Ferrari, L. (2000). Biomarkers assessment in juvenile Cyprinus carpio exposed to waterborne cadmium. Environmental Pollution, 109, 277-282. doi:10.1016/S0269-7491(99)00263-8

De La Torre, F., Salibian, A., \& Ferrari, L. (2007). Assessment of the pollution impact on biomarkers of effect of a freshwater fish. Chemosphere, 68, 1582-1590. doi: 10.1016/j.chemosphere.2007.02.033

Di Giulio, R.T., C.S. Jewell, P.C. Washburn, R., Wenning, J., \& Winston, G.W. (1989). Biochemical responses in aquatic animals: a review of determinants of oxidative stress. Ecotoxicology and Environmental Safety, $8,1103-1123$.

El-Serafy, S. S., Zowail M. E, Abdel-Hameid, N. H., Awwad, M. H., \& Omar, E.H. (2013). Effect of dietborne $\mathrm{Cu}$ and $\mathrm{Cd}$ on body indices of Nile Tilapia (Oreochromis niloticus) with emphasis on protein pattern. Turkish Journal of Fisheries and Aquatic Sciences, 13, 593-602. doi: 10.4194/1303-2712-v13_4_04

Elia, A. C., Galarini, R., Taticchi, M. I., \& Dorr, A. J. M. (2003). Mantilacci L. Antioxidant responses and bioaccumulation in Ictalurus melas under mercury exposure. Ecotoxicology and Environmental Safety, 55, 162-167. doi: 10.1631/jzus.B0710624

Habig, W. H., Pabst, M. J. \& Jakoby, W. B. (1974). Glutathione S- transferases the first enzymatic step in mercapturic acid formation. Journal of Biological Chemistry, 249, 7130-7139.

Handy, R. D. (2003). Chronic effects of copper exposure versus endocrine toxicity: two sides of the same toxicological proces, Comparative Biochemistry and Physiology - Part A, 135, 25-38. doi: 10.1016/S1095-6433(03)00018-7

Hayes, J. D., Flanagan, J. U. \& Jowsey, I. R. (2005). Glutathione transferases. Annual Reviews. Pharmacology and Toxicology, 45, 51-88. doi: 10.1146/annurev.pharmtox.45.120403.095857

Hunn, J. B. (1985). Role of calcium in gill function in freshwater fishes. Comparative Biochemistry and Physiology, 82A, 543-547.

Karthikeyan, S. \& Mani, P. (2014). Effect of heavy metals on tissue protein of an edible fish Cirrhinus mrigala as dependent on $\mathrm{pH}$ and water hardness, Biophysics, 59(59),321-325. doi: 10.1134/S0006350914020110

Karthikeyan, S., Palaniappan P. L. R. M., \& Sabhanayakam, S. (2007). Influence of pH and water hardness upon nickel accumulation in edible fish Cirrhinus mrigala. Journal of Environmental Biology, 28(2), 489-492. 
Lall, S.P. (2002). The minerals. In: Halver, J.E., Hardy, R.W. (Eds.), Fish Nutrition. Academic Press, London, p. 289.

Liu, Y., Zhang, Y., Liu J., \& Huang, D. (2006). The role of reactive oxygen species in the herbicide acetachlorinduced DNA damage on Bufo-raddei tadpole liver. Aquatic Toxicology, 78, 21-26. doi: 10.1016/j.aquatox.2006.01.016

Livingstone, D.R. (2003). Oxidative stress in aquatic organisms in relation to pollution and aquaculture. Revue De Medecine Veterinaire, 154, 427-430.

Lowry, O. H., Rosenbrough, N. J., Farr, A. L., \& Randall, R.J. (1951). Protein measurement with the folin phenol reagent. Journal of Biological Chemistry, 193, 266-275.

Matsuo, A.Y.O., Playle, R.C., Val, A.L., \& Wood, C.M., (2004). Physiological action of dissolved organic matter in rainbow trout in the presence and absence of copper: sodium uptake kinetics and unidirectional flux rates in hard and softwater. Aquatic Toxicology, 70, 63-81. doi: 10.1016/j.aquatox.2004.07.005

Mela, M., Guiloski, I. C., Doria, H. B., Rabitto, I. S. Silva, C. A. Maraschi, A. C., Prodocimo, V., Freire, C.A., M. A. F. Randi, C. A., Oliveira Ribeiro, H. C., \& Assis S. (2013). Risks of waterborne copper exposure to a cultivated freshwater Neotropical catfish (Rhamdia quelen). Ecotoxicology and Environmental Safety, 88, 108-116. doi: 10.1016/j.ecoenv.2012.11.002

Mohamed, F.A., \& Gad, N.S., (2008). Environmental pollution induced biochemical changes in tissues of Tilapia zillii, Solea vulgaris and Mugil capito from Lake Qarun, Egypt Global Veterinaria, 2(6), 327-336

Monteiro, D. A., J. A. D. Almeida, F., Rantin, T., \& A.L. Kalinin, (2006). Oxidative stress biomarkers in the freshwater characid fish Brycon cephalus, exposed to organophosphorus insecticide Folisuper 600 (Methyl parathion). Comparative Biochemistry and Physiology - Part C: Toxicology, 143, 141 - 149. doi: 10.1016/j.cbpc.2006.01.004

Pereira, S., Pinto, A.L., Cortes, R., Fontaínhas-Fernandes, A., Coimbra, A., \& Monteiro. S. (2013). Gill histopathological and oxidative stress evaluation in native fish captured in Portuguese northwestern rivers. Ecotoxicology and Environmental Safety, 90, 157-166. doi: 10.1016/j.ecoenv.2012.12.023

Ransberry, V. E., Morash, A. J., Blewett, T. A., Wood, C. M., \& McClelland, G. B. (2015). Oxidative stress and metabolic responses to copper in freshwater- and seawater-acclimated Killifish, Fundulus heteroclitus. Aquatic Toxicology, 161, 242-252. doi: 10.1016/j.aquatox.2015.02.013

Sanchez, W, Palluel, O, Meunier, L, Coquery, M, Porcher, J.M., \& Aitssa S. A. (2005). Copper-induced oxidative stress in three-spined stickleback: relationship with hepatic metal levels. Environmental Toxicology and Pharmacology, 19, 177-183. doi: 10.1016/j.etap.2004.07.003

Santore, R.C., Di Toro, D. M., Paquin, P. R., Allen, H. E., \& J. S. Meyer (2001). Biotic ligand model of the acute toxicity of metals. 2. Application to acute copper toxicity in freshwater fish and Daphnia. Environmental Toxicology and Chemistry, 20, 2397-2402. doi: 10.1002/etc.5620201035

Santovito, G., Piccinni, E., Boldrin F., \& Irato, P. (2012). Comparative study on metal homeostasis and detoxification in two Antarctic teleosts. Comparative Biochemistry and Physiology, Part C 155, 580-586. doi: 10.1016/j.cbpc.2012.01.008

Scott, G.R., Baker, D.W., Schulte, P.M., \& Wood, C.M. (2008). Physiological and molecular mechanisms of osmoregulatory plasticity in killifish after seawater transfer. Journal of Experimental Biology, 211, 24502459. doi: 10.1242/jeb.017947

Simonato, J. D., Mela, M., Doria, H. B., Guiloski, I. C., Randi, M. A. F., Carvalho, P. S. M., Meletti, P. C., Silva de Assis, H. C., Bianchini, A., \& Martinez C.B.R. (2016). Biomarkers of waterborne copper exposure in the Neotropical fish Prochilodus lineatus. Aquatic Toxicology, 170, 31-41. doi: 10.1016/j.aquatox.2015.11.012.

Sun, X., Shih, A.Y., Johannssen, H.C., Erb, H., Li, P., \& Murphy, T.H. (2006). Two-photon imaging of glutathione levels in intact brain indicates enhanced redox buffering in developing neurons and cells at the cerebrospinal fluid and blood-brain interface. Journal of Biological Chemistry, 23(25), 281doi: 17420-31. 10.1074/jbc.M601567200

Tripathi, B.N., Mehta, S.K., Amar, A., \& Gaur, J.P. (2006) Oxidative stress in Scenedesmus sp. during short-and long-term exposure to $\mathrm{Cu}^{2+}$ and $\mathrm{Zn}^{+}$. Chemosphere, 62, 538-544. doi: 10.1016/j.chemosphere.2005.06.031

Qu, R., Wang, X., Wang, Z., Wei, Z., \& Wang, L. (2014). Metal accumulation and antioxidant defenses in the freshwater fish Carassius auratus in response to single and combined exposure to cadmium and hydroxylated multi-walled carbon nanotubes. Journal of Hazardous Materials, 30(275),89-98. doi: 10.1016/j.jhazmat.2014.04.051

Vijayan, M. M., Pereira, C., Grau, E. G., \& Iwama, G.K. (1997). Metabolic responses associated with confinement stress in tilapia; the role of cortisol. Journal of Biochemistry and Physiology C, 116 (1), 8995. doi: 89-85. 10.1016/S0742-8413(96)00124-7 